\title{
Mensuration of Quadrilaterals in the Lìlāvatī
}

\author{
S.G. Dani
}

\begin{abstract}
Mensuration with quadrilaterals had received attention in the Siddhānta tradition at least since Brahmagupta. However, in Bhāskaracārya's Lìlāvat̄̄ we come across some distinctively new features. In this paper an attempt will be made to put the development in historical perspective.
\end{abstract}

A systematic study of the topic of mensuration of quadrilaterals in Indian mathematics goes back at least to the Brāhmasphutasiddhānta (628 CE) of Brahmagupta (born in $598 \mathrm{CE}$ ); in certain special cases, such as isosceles trapezia, some familiarity is found in the Ślvasūtras from around the middle of the first millennium BCE (see Sen and Bag 1983 1 ). With regard to mensuration of quadrilaterals Brahmagupta is well-known for the formula in the sütra:

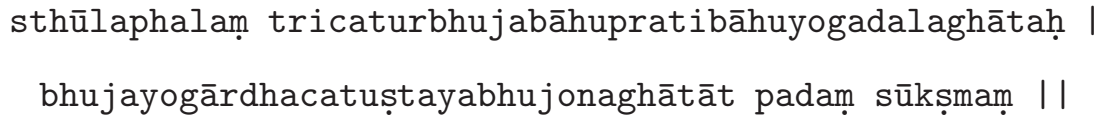

Brāhmasphuțasiddhānta (XII - 21)

Traditionally the sūtra has been understood, by ancient mathematicians following Brahmagupta (I shall dwell more on this later), as well as modern commentators broadly as follows:

The gross area of a triangle or quadrilateral is the product of half the sum of the opposite sides. The exact area is the square-root of the product of the four sets of half the sum of the sides (respectively) diminished by the sides.

This translation is taken from Saraswati 19792(p. 88), and the translations in Colebrooke 18173 and Plofker 20094 also correspond to it. In all of these, in

\footnotetext{
${ }^{1}$ Sen and Bag 1983 : S.N. Sen and A.K. Bag, The Śulvasūtras, Indian National Science Academy, New Delhi, India, 1983

${ }^{2}$ Saraswati 1979 : T.A. Saraswati Amma, Geometry in Ancient and Medieval India, Motilal Banarasidas Publishers, Delhi, India, 1979, reprinted in 1999.

${ }^{3}$ Colebrooke 1817 : H.T. Colebrooke, Algebra, arithmetic and mensuration, from the original Sanscrit, of Brahmegupta and Bhaskara, Translation, John Murray, Albemarle Street, London, UK, 1817.

${ }^{4}$ Plofker 2009 : Kim Plofker, Mathematics in India, Princeton University Press, Princeton, NJ, USA, 2009. xiv+357 pp.
} 
particular, tricaturbhuja is interpreted as referring to the formula being applicable to triangles and quadrilaterals (independently). For the case of the triangle this is the well-known formula known after Heron of Alexandria (1st century CE), and in this context the quadrilateral version is referred to as "Brahmagupta's generalization" (see, for instance, Plofker 2009, p. 144). The general version, which in modern notation may be stated as

$$
A=\sqrt{(s-a)(s-b)(s-c)(s-d)}
$$

where $a, b, c, d$ are the sides of the quadrilateral, $s$ is half the perimeter, and $A$ is the area, is however correct only when the quadrilateral is cyclic, viz. when all the four vertices lie on a common circle; this condition holds for quadrilaterals like rectangles and isosceles trapezia, but not in general, e.g. for rhombuses with unequal diagonals. The general perception in the context of the interpretation has been that the author somehow omitted to mention the condition, though actually aware of it, with the latter being confirmed by the fact that he is noted to apply it only for cyclic quadrilaterals.

It has however recently been argued in Kichenassamy 20105 that actually the term tricaturbhuja was in fact used by Brahmagupta to mean a cyclic quadrilateral (and not triangle and/or quadrilateral). Thus Brahmagupta means to state

The gross area of a cyclic quadrilateral is the product of half the sum of the opposite sides, and the square-root of the product of the four sets of half the sum of the sides (respectively) diminished by the sides is the exact area.

A bit of a hint towards that the traditional interpretation may not be right is contained in the fact that at the only other place where the term tricaturbhuja occurs in Brāhmasphutasiddhānta, in sūtra (XII - 27), (and it is not known to occur in earlier or later ancient texts) the result involved (relating to the circumradius) is stated first for triangles, separately, and then for "tricaturbhuja"s which indicates that the latter should in fact have four sides (see Kichenassamy 20136). The arguments in Kichenassamy 2010, go well beyond that, with the author providing a detailed discussion on the issue, including on how Brahmagupta would have arrived at the formula, and how it incorporates in a natural way the hypothesis

\footnotetext{
${ }^{5}$ Kichenassamy 2010 : S. Kichenassamy, Brahmagupta's derivation of the area of a cyclic quadrilateral, Historia Math. 37 (2010), 28 - 61.

${ }^{6}$ Kichenassamy 2013 : S. Kichenassamy, Textual analysis of ancient Indian mathematics, Gaṇita Bhāratī 33 (2011), 15 - 28 (2013).
} 
that the quadrilateral is cyclic. According to Kichenassamy, Brahmagupta while pursuing his study of triangles dealt with the circumcircle, described in particular a formula for the circumradius, and along the line of thought considered quadrilaterals formed by the triangle and a point on the circumcircle, which motivated the term tricaturbhuja. 7

Unfortunately, the theory developed by Brahmagupta did not go down the line of later mathematicians in India with proper understanding. It may be worthwhile to recall the following in this respect. Let us consider the works

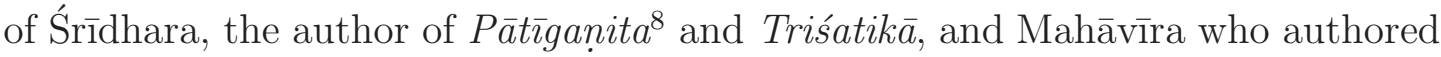
Ganitasārasangrahd9, two prominent authors 10 from the intervening period between Brahmagupta and Bhāskara. Mahāvīra is known to be from around $850 \mathrm{CE}$. Concerning Śrīdhara there has been a controversy among scholars over his period, and in particular over whether he was anterior or posterior to Mahāvīra, but it now seems to be agreed that he is from the 8th century 11

\footnotetext{
${ }^{7}$ In a recent paper (not yet published) P.P. Divakaran proposes a somewhat different scenario for the development of ideas in Brahmagupta's work and the genesis of the term tricaturbhuja, which nevertheless discounts the traditional interpretation of the term mentioned earlier.

${ }^{8}$ Śrīdhara, Pātīganita: The Pātīganita of Śrīdharacārya with an anciet Sanskrit commentary, ed \& tr, Kripa Shankar Shukla, Hindu Astronomical and Mathematical Texts Series No. 2, Department of Mathematics and Astronomy, Lucknow University, Lucknow, India, 1959.

${ }^{9}$ Mahāvīra, Ganitasārasañgraha: Mahāvīra, Ganitasārasañgraha, ed \& tr Dr. (Mrs.) Padmavathamma, Publ. by Sri Hombuja Jain Math, Hombuja, Shimoga District, Karnataka, India, 2000.

${ }^{10}$ As noted by K.S. Shukla in the introduction to his edition of Śrīdhara's Pātıganita, Śrīdhara's works are cited by many later authors. On the other hand Mahāvīra's Ganitasārasañgraha apparently enjoyed the status of a textbook in many parts of South India for nearly three centuries, until the arrival of Bhāskarācārya's Lìlāvatū, as noted by Balachandra Rao, in his review (in Gaṇita BhāratīVol. 35 (2013), p. 167) of the book Śr $r \bar{\imath}$ Rājāditya' Vyavahāraganita edited and translated by Padmavathamma, Krishnaveni and K.G. Prakash.

${ }^{11}$ In $\S 5$ of Shukla's introduction to his edition of Śrīdhara's Pātīganita, one finds a detailed discussion on this issue, concluding with his own verdict that Śrīdhara "lived sometime between Mahāvīra (850) and Āryabhața II (950)". Saraswati 1979 expresses skepticism in this respect (See page 10; her wording is "Śrīdhara is probably earlier than Mahāvīra though K.S. Shukla places him betewen 850 and 950 A.D."). S.D. Pathak, in his paper Śrìdhara's time and works, Gaṇita Bhāratī, Vol 25 (2003), 146-149, which was published posthumously but was actually written before Shukla's edition of Pātīganita was published, argues in favour of Śrīdhara being earlier, and, notably, in a special note following the article the Editor R.C. Gupta, who had himself also discussed the issue in an earlier paper, mentions "But now Dr. Shukla himself accepts the priority of Śrīdhara over Mahāvīra (personal discussions)". Also, Shefali Jain in her recent thesis Ācarya Śrīdhar evam acārya Mahāvīra ke Ganiteeya avadano ka tulanatmak adhyayan (Ph.D. Thesis, Shobhit Vishwavidyala Meerut, India, 2013.) mentions that at the end of a manuscript of Ganitasārasangraha in the Royal Asiatic Society, Bombay (MS No. 230) one finds the statement "kramādityuktam Śrīdharācaryeṇa bhadram bhūyāt" which shows that
} 
In Pātīganita, on the issue of areas of quadrilaterals Śrīdhara first gives a formula for the areas of trapezia (the usual one), in sūtra 115 which is then complemented, in sūtra 117 (see Śrīdhara, Pātīganita, ed. K.S. Shukla, p. 175), with the following:

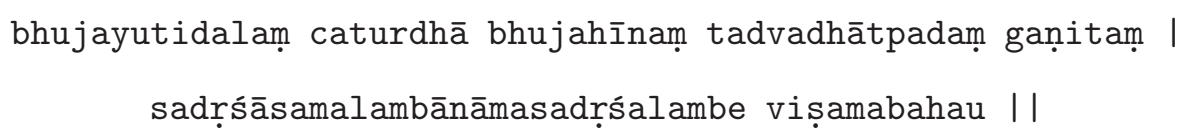

Pātīganita (117)

Set down half the sum of the (four) sides (of the quadrilateral) in four places, (then) diminish them (respectively) by the (four) sides (of the quadralateral), (then) multiply (the resulting numbers) and take the square root (of the product): this gives the area of the quadrilaterals having (two or more) equal sides but unequal altitudes and also of quadrilaterals having unequal sides and unequal altitudes. (Translation from Śrīdhara, Pātìganita, ed \& tr K.S. Shukla.)

Thus Śrīdhara is seen to give formula $(*)$ for the area of any quadrilateral, dwelling elaborately on the generality, without realising that it is not true in that generality. Interestingly, unlike in the case of the formula for trapezia, no examples are discussed to illustrate the general formula. This suggests in a way that the sūtra is included in the spirit of recording and passing on a piece of traditional knowledge in which the author espouses no direct interest; this is a kind of situation in which mathematicians are prone to let down their guard! His treatment in Triśatika is also along the same lines (See Saraswati 1979, p. 92).

Mahāvīra states the result under discussion as follows:

bhujayutyardhacatuṣkādbhujahīnaddhātitatpadam sūkṣmạ̣ |

first half of Ganitasārasañgraha (VII - 50)

Four quantities represented (respectively) by half the sum of the sides as diminished by (each of) the sides (taken in order) are multiplied together and the square root (of the product so obtained) gives the minutely accurate measure (of the area of the figure). - (Translation from Mahāvīra, Gaṇitasārasañgraha, ed Padmavathamma).

Śīdhara preceded Mahāvīra. In the light of earlier literature she assigns $750 \mathrm{CE}$ as the year around when he would have flourished. 
Here again formula $(*)$ is stated unconditionally for any quadrilateral. The second half of the above mentioned verse is the usual formula for the area of a trapezium, as the product of the perpendicular height with half the sum of the base and the opposite side, mentioning also a caviat that it does not hold for a visamacaturasra. In verses 51-53 following the sūtra as above, Mahāvīra asks to compute the areas of tringles with given lengths for their sides, presumably meant to be done using the first part of verse 50 . verse 54 describes a formula for the diagonal of a quadrilatera 12 and in verses 55 to 57 the author asks to compute diagonals and areas of quadrilaterals which are isosceles trapezia; since reference to diagonals is also invoked it is not clear whether the computation is meant to be done using the general form of verse 50 , namely formula $(*)$, or by first computing the diagonal. As a whole the treatment suggests a lack of interest (perhaps coupled with disbelief) in the general case of the formula.

Similarly, Śrīpati (11th century) also gives, in Siddhāntaśekhara, formula (*) unconditionally (see Saraswati 1979, p. 94). On the whole the practice of treating the expression as the formula for the area of any quadrilateral was so prevalent that one finds it presented as such even in the 14th century work Ganitasārakaumud $\bar{\imath}$ of Thakkura Pherū (see SaKHYa, 200913, p. 142). Notwithstanding the overall continuity of the Indian mathematical tradition, topics that were not directly involved in practice, in astronomy or other spheres in which mathematics was applied at the time, suffered neglect, and sometimes were carried forward without a proper understanding of what was involved.

By the time of Bhāskara any connection of the formula $(*)$ with cyclicity of the quadrilateral was completely lost. Even awareness of cyclic quadrilaterals seems to have gone missing over a period, until it was resurrected in the work of Nārāyaṇa Pandita, in the 14th century (See Saraswati, 1979, pages 96-106, for details).

In this overall context, as it prevailed around the turn of the millennium, Āryabhața II, who is believed to have lived sometime between 950 and $1100 \mathrm{CE}$ (see Plofker 2009, p. 322), rejected (*) as the formula for the area of a quadrilateral, ridiculing one who wants to find the area of a quadrilateral without knowing the length of a diagonal as a fool or devil (mūrkhah piśāco vā) (see Saraswati 1979, p. 87). This was the situation when Bhāskara appeared on the scene. Though

\footnotetext{
${ }^{12}$ This formula also goes back to Brahmagupta and is valid only for cyclic quadrilaterals, but is stated here unconditionally.

${ }^{13}$ SaKHYa, Ganitasārakaumudī; the Moonlight of the Essence of Mathematics, by Thakkura Pher $\bar{u}$; edited with Introduction, Translation, and Mathematical Commentary, Manohar Publishers, New Delhi, India, 2009.
} 
apparently guided by Āryabhața II in his treatment in respect of Brahmagupta's theorem (see Saraswati, 1979, p. 94) Bhāskara took an entirely different approach to the issue, bringing considerable clarity on the topic (even though he did not get to cyclic quadrilaterals).

A closer look at the relevant portion of the Lìlavatī shows an intense concern on the part of Bhāskara at what he observed as a flaw in the "traditional" formula. This does not seem to have been adequately appreciated in the literature on the topic. One of the reasons for this seems to be that the standard translation cum commentaries (E.g. Colebrooke 199314, Phadake 1971논, Patwardhan-Naimpally-

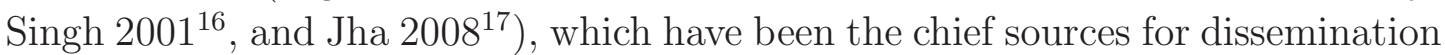
of the topic, have translated and commented upon the sūtras involved only individually, in a rather disjointed way, as a result of which a common strand that Bhāskara followed in respect of the above seems to have been missed. Secondly, many of the commentaries, except Colebrooke 1993 from the above, while including the text of the Lìlāvat̄̄ do not include Bhāskara's Vāsanābhāṣya (explanatory annotation, in prose form, on the original verse text) along with it; also, even as they are seen to avail of various points made in $V \bar{a} s a n \bar{a} b h \bar{a} s y a$, no reference is made to the latter, which diffuses the overall picture even further. Colebrooke, 1993, does include Vāsanābhāsya and also a meticulous translation of it for the most part, though as I shall point out below a crucial line relevant to the theme under discussion is missing from the translation 18 .

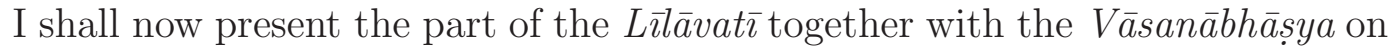
the issue as above and bring out the strand of Bhāskara's thinking, and concern, over the perceived flaw.

Let me begin with Bhāskarācārya's statement on the formula (for reference to the verses I shall indicate their numbers in Colebrooke 1993 and also Apte 193719,

14 Colebrooke 1993 : H.T. Colebrooke, Translation of the Lilavati, with notes by Haran Chandra Banerji, Second Edition, Asian Educational Services, New Delhi, Madras, India, 1993.

${ }^{15}$ Phadake 1971 : N.H. Phadake, Shrimad Bhaskaracharya krta Līlāvatī Punardarshan, (in Marathi), Sarita Prakashan, Pune, India, 1971, last reprinted 2014.

${ }^{16}$ Patwardhan-Naimpally-Singh 2001 : K.S. Patwardhan, S.A. Naimpally and S.L. Singh, Lūlāvat̄̄ of Bhāskarācārya, A Treatise of Mathematics of Vedic Tradition, Motilal Banarasidas Publishers, Delhi, India, 2001.

${ }^{17}$ Jha 2008 : Pandit Shrilashanlal Jha, Shrimad Bhaskaravirachita Lilavati (in Hindi), Chaukhamba Prakashan, Varanasi, India, 2008.

${ }^{18}$ Similarly some other short segments aimed at introducing the subsequent verse have been omitted from the translation elsewhere in the text.

19 Apte 1937 : Vinayak Ganesh Apte, Buddhivilāsin̄̄ Lìlāvatīvivaranākhyatīkādvayopeta Śhrīmad Bhāskarācāryaviracita Lūlāvatī (in Sanskrit), Ānandāshram Mudraṇālaya, Pune, India, 1937. 
the standard Sanskrit sourcebook on the topic; the latter number will be put between square bracket, following the former, separated by a colon. The reader is cautioned that the numbers vary somewhat according to the reference concerned):

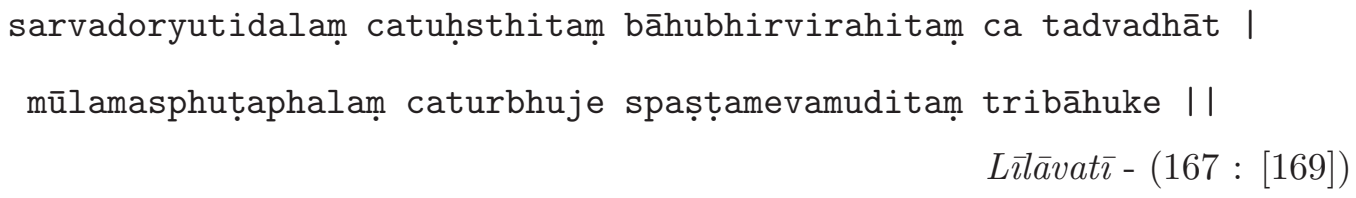

Half the sum of all the sides is set down in four places; and the sides are severally subtracted. The remainders being multiplied together, the square root of the product is the area, inexact in the quadrilateral, but pronounced exact in the triangle. - (The translation is taken from Colebrooke, 1993; I have added a comma, after "area", which seems to be needed for easy comprehension.)

Thus, unlike Āryabhaṭa II, Bhāskara does not reject outright the formula for the quadrilateral, accepting it only for triangles. He mentions it as exact (spașta) for triangles while for quadrilaterals he calls is "inexact" (asphuta). This is however only the beginning. Detailed comments on it are to follow.

To begin with he asks, in verse (168: [170]), for the area to be computed "as told by the ancients" (tatkathitam yadadyaih) for a quadrilateral with base (bhümi) 14, face (mukha) 9, sides 13 and 12, and perpendicular 12; it can be seen that the quadrilateral is a non-isosceles trapezium, formed by attaching to a rectangle with sides 9 and 12, a right angled triangle with sides 5, 12 and 13, along the side with length 12 . In the Vāsanābhāsya Bhāskara proceeds to note that the area given by the formula is $\sqrt{19800}$, which is "a little less than 141", while the actual area (which can be computed for a trapezium more directly) is 138 , thus pointing to a contradiction.

Though this would have sufficed for the contention that the formula is not correct, or accurate, Bhāskara does not leave it at that. He embarks on a more detailed discussion on the issue. At the beginning of verse (169 : [171]), in the Vāsanābhāṣya the Ācārya says:

atha sthūlatvanirūpaṇārtham sūtram sārdhavṛttạ̣ |

Now a sütra of a stanza and half for looking into the grossness. (My translation). 
This line, which is significant from our point of view, is not found in the translation in Colebrooke, 1993 (as noted earlier many other sources do not include the text of the Vāsanābhāsya either). We note that "atha" marks commencement (of a story, chapter, argument etc., typically in a ceremonial way) and that nirūpana means "looking into, analysis or investigation". sthülatva stands for "grossness" or "coarseness": thus Bhāskara is announcing here that he is taking up an analysis of the grossnes 20 (of the formula). This is followed by the following argument:

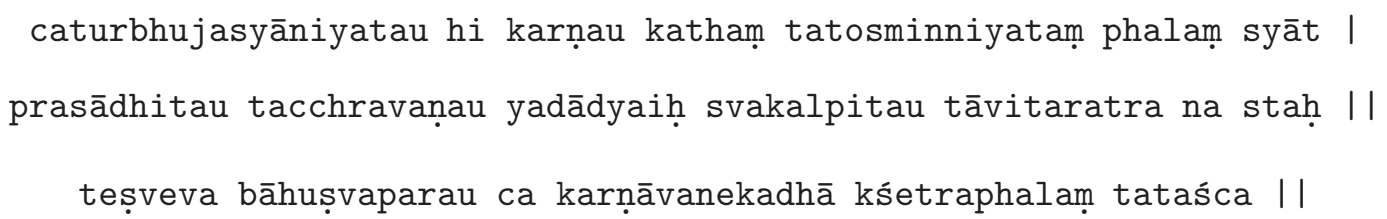

The diagonals of a quadrilateral are indeterminate (aniyatau); then how could the area [confined] within them be determinate? The (values for) diagonals set down (prasādhitau) by the ancients would not be the same elsewhere. For the same (choices of the) sides the diagonals have many possibilities and the area would vary accordingly. (My translation).

In the $V \bar{a} s a n \bar{a} b h \bar{a} s y a$ this is further elaborated, noting that if in a quadrilateral two opposite vertices are moved towards each other then the diagonal between them contracts, while the other two vertices move away from each other and the diagonal between them elongates, and thus with sides of the same length there are other possible values for the diagonals.

The next verse in the Lìlâvatī raises some rhetorical questions:

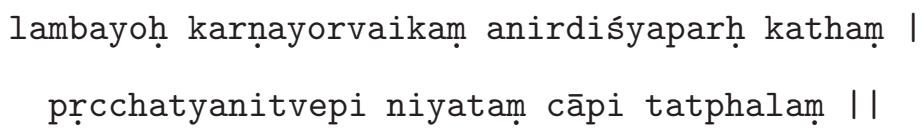

Lìlāvatì (171 : [173])

\footnotetext{
${ }^{20}$ Like the English word adopted here for sthülatva, the latter also has shades of meaning of unflattering variety, and one may wonder whether the choice of the word sthülatva here, as against say the noun form of the adjective asphuta that was adopted in the original sutra), is deliberate.
} 
When none of the perpendiculars nor either of the diagonals are specified, how will the other values get determined? It is like asking for definite area, when in fact it is indeterminate. (My translation).

Then come some devastating blows:

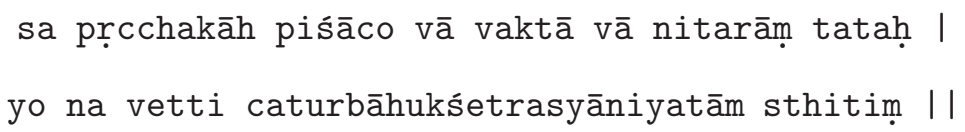

Lìlāvatı̄ (172 : [172])

Such a questioner is a blundering devil (piśāca) and worse is one who answers it. They do not realise the indeterminate nature of the area of a quadrilateral. (My translation).

The scorn being deployed is reminiscent of Aryabhata II, but here we find it accentuated, and its scope extended to those answering the question!

Having vented his ire over the ignoramuses the Ācārya next sets out to establish the point through more concrete illustrations. Before continuing with it, it may be worthwhile to note the following. While the argument given in (169-170) is of considerable heuristic value, it is not conclusive from a logical point of view, since so far it has not been shown that when the sides are the same and diagonals vary the areas could actually be different. To make the argument foolproof, and to fully convince skeptics, one needs concrete examples, with same four sides and different pairs of diagonals for which the areas are verifiably different. While he may or may not have have specifically followed such a train of thought, that is what Bhāskara sets out to do in the following verses.

For the illustrations he needs situations where after making alterations as proposed in the Vāsanābhāṣya following sutras (169-170: [171]) it would be possible to readily compute the area (and show that it is different). For this purpose he considers the class of equilateral quadrilaterals (in which all sides are equal, also called rhombuses). He notes a formula for the second diagonal, given the common value of the side and one of the diagonals: in modern notation, if $a$ is the side and $d_{1}$ and $d_{2}$ are the diagonals then

$$
d_{2}=\sqrt{4 a^{2}-d_{1}^{2}}
$$


He recalls also the formula for the area, as equal to $\frac{1}{2} d_{1} d_{2}$; the sutras (174-175) involving this include also statement of areas of rectangles and trapezia, but that is purely to put the situation of equilaterals in context - after all, the knowledge of these is already implicit in particular in the problem posed in verse (169: [170]).

At this juncture one is in a position to illustrate the point that was made following (169-170 : [171]), since if we start with an equilateral quadrilateral with side $a$ and a diagonal of size $d_{1}$ and move the vertices on the two sides of that diagonal closer along the diagonal, then the area is $\frac{1}{2} d_{1} \sqrt{4 a^{2}-d_{1}^{2}}$, with $d_{1}$ as a variable quantity; one can readily see that choosing different values of $d_{1}$ we get rhombuses with the same side-lengths but different areas. However, not content with this, he seeks more concrete choices for the side and diagonal, specifically with integer values. For this purpose he brings in his knowledge of what are now called Pythagorean triples. A Pythagorean triple is a triple of natural numbers $(l, m, n)$ such that $l^{2}+m^{2}=n^{2}$; by the Pythagoras theorem (or rather its converse, which can be deduced from the theorem itself, via elementary geometry) for a triangle with sides $l, m$ and $n$ where $(l, m, n)$ is a Pythagorean triple, the angle opposite to the side $n$ is a right angle. Putting 4 such right angled triangles together, along their equal sides adjacent to the right angles, we get an equilateral quadrilateral with all sides $n$ and diagonals $2 l$ and $2 m$ respectively, and their areas are $2 \mathrm{~lm}$. Bhāskara now chooses the triples $(15,20,25)$ and $(7,24,25)$ which are seen to be Pythagorean 21 , and have common value for the length of the hypotenuse. Thus the construction as above yields two equilateral quadrilaterals with areas $2(15 \times 20)=600$ and $2(7 \times 24)=336$, respectively. Bhāskara also points out that we may also consider for comparison the square with all sides 25 , in which case the area is 625 , a yet another value for the area.

Thus Bhāskara adopts various means, argumentation, pressurising through rhetoric, as well as persuasion, to put it across to his readers that Brahmagupta's formula is not valid exactly for a general quadrilateral.

Following the group of versers discussed above, there are two more problems concerning the area of a quadrilateral. In verse (177: [175]) we have an example of (what turns out to be) a non-isosceles trapezium, for which again it is pointed out, in $V \bar{a} s a n \bar{a} b h \bar{a} s y a$, that the area computed using $(*)$ does not give the true value.

The next verse, (178: [176]), asks to find the area, and also the diagonals and

\footnotetext{
${ }^{21}$ It may be recalled here as an aside that Pythagorean triples have been known in India since the time of Ślvasūtras; for a discussion on such triples occurring in Sulvasūtras the reader is referred to: S.G. Dani, Pythagorean triples in Śulvasūtras, Current Science 85 (2003), 219 - 224.
} 
perpendiculars, of a quadrilateral whose sides are given as, face 51, base 75, left side 68 and right side 40. To a discerning reader it should seem puzzling that the Ācārya should ask such a question, giving only the sizes of the four sides, after all the painstaking endeavour to get it across that sizes of four sides do not determine a quadrilateral, and in particular the area is indeterminate. It is hard to reconcile this especially with verse (172: [172]), according to which one asking such a question is a "piśāca".

The spirit of what follows however seems to be to explain how one should proceed in response, when such a problem is posed (e.g. as a challenge); since at one time the focus was on cyclic quadrilaterals which were determined once the sides were given (together with their order) it may have been a general practice to pose questions about quadrilaterals purely in terms of their sides (in specific order). In the next verse Bhāskara recalls that if we know the perpendicular that determines the (corresponding) diagonal, and knowing a diagonal determines the (corresponding) perpendicular, and the area; this is consistent with the earlier contention about the need for an additional assumption being necessary. In his

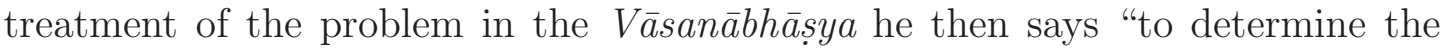
perpendicular we assume the diagonal joining the tip of the left side to the base of the right side to be (of length) 77" (emphasis added). With this choice for the diagonal the perpendicular and then the area of the quadrilateral are computed (adding the areas of the two triangles on the two sides of the diagonal as above)22; it turns out to be 3234 . Interestingly, this is the value that one would get from $(*)$ with the values 51, 68, 75 and 40 for the four sides! (One may wonder whether Bhāskara intended this, but there is no way to know.) The reason for this agreement, from a modern perspective, is of course that for the above choice of the diagonal the quadrilateral is cyclic, and Brahmagupta's formula does apply.

It would seem curious that the choice made was such that the quadrilateral is cyclic, especially when there is no reference to such a concept in the text. Also, though the fact of having to make a choice has been clarified, one would wonder how the choice of 77 as the length of the (particular) diagonal came about, especially in the context of its turning out to be one for which the quadrilateral is cyclic; it may be noted that if one starts with an ad hoc choice the computations of the perpendicular and the area involve rather complicated surds, making it unsuitable for an illustrative example. All commentators have repeated the part

\footnotetext{
${ }^{22}$ Having assumed the diagonal to have length 77 , the areas of the two triangles formed could be computed using $(*)$, which Bhāskara does consider to be exact for triangles, but the method given goes through the computation of the perpendicular, and no reference is made to this other possibility.
} 
about assuming the (particular) diagonal to be 77 (generally without reference to the Vāsanābhāsya), but throw no light on the issue of what motivates the specific value that is chosen. It seems that this quadrilateral was familiar to Bhāskara, together with the value for the diagonal. Brahmagupta had given a construction (Brāhmasphutasiddhānta, XII - 38) of quadrilaterals with integer values for the sides and area, starting with a pair of Pythagorean triples (the reader is referred to Pranesachar, 201223 for an exposition on this), and it has been recalled in the Lìlāvatī (sūtras 191-192 : [186-187]). For each quadrilateral constructed using the Brahmagupta construction (which necessarily turn out to be cyclic) one gets some new ones (with vertices on the same circle as the original one) by replacing the triangle on one side of a diagonal by its reflection in the perpendicular bisector of the diagonal. This process of obtaining new quadrilaterals also turns up in the Lìlāvatì (though there is no reference to their cyclicity along with it). Commentator Ganeśa has pointed out that the quadrilateral with sides 51, 68, 75 and 40 as in the above discussion is one of the quadrilaterals arising in this way, starting with the Pythagorean triples $(3,4,5)$ and $(8,15,17)$ (cf. Colebrooke, 1993, p. 127-128).

\section{S.G. Dani}

Department of Mathematics

Indian Institute of Technology Bombay

Powai, Mumbai 400076

India

E-mail : sdani@math.iitb.ac.in

\footnotetext{
${ }^{23}$ C.R. Pranesachar, Brahmagupta, mathematician par excellence, Resonance, March 2012, 247 - 252.
} 


\section{References}

[1] Vinayak Ganesh Apte, Buddhivilāsin̄̄ Lìlāvatīvivaran̄ākhyatīkādvayopeta Śhrīmad Bhāskarācāryaviracita Līlāvat̄̄ (in Sanskrit), Ānandāshram Mudraṇālaya, Pune, 1937.

[2] H.T. Colebrooke, Algebra, arithmetic and mensuration, from the original Sanscrit, of Brahmegupta and Bhaskara, Translation, John Murray, Albemarle Street, London, 1817.

[3] H.T. Colebrooke, Translation of the Lilavati, with notes by Haran Chandra Banerji, Second Edition, Asian Educational Services, New Delhi, Madras, 1993.

[4] S.G. Dani, Pythagorean triples in Śulvasūtras, Current Science 85 (2003), $219-224$.

[5] Shefali Jain, Ācarya Srīdhar evam acārya Mahāvīra ke Ganiteeya avadano ka tulanatmak adhyayan; Ph.D. Thesis, Shobhit Vishwavidyala Meerut, 2013.

[6] Pandit Shrilashanlal Jha, Shrimad Bhaskaravirachita Lilavati (in Hindi, Chaukhamba Prakashan, 2008.

[7] S. Kichenassamy, Brahmagupta's derivation of the area of a cyclic quadrilateral, Historia Math. 37 (2010), 28 - 61.

[8] S. Kichenassamy, Textual analysis of ancient Indian mathematics, Ganita Bhāratī 33 (2011), 15 - 28 (2013).

[9] K.S. Patwardhan, S.A. Naimpally and S.L. Singh, Līlāvat̄̄ of Bhāskarāāarya, A Treatise of Mathematics of Vedic Tradition, Motilal Banarasidas Publishers, Delhi 2001.

[10] N.H. Phadake, Shrimad Bhaskaracharya kṛta Līlāvat̄̄ Punardarshan, (in Marathi), Sarita Prakashan, Pune 2014.

[11] Kim Plofker, Mathematics in India, Princeton University Press, Princeton, NJ, 2009. xiv+357 pp.

[12] C.R. Pranesachar, Brahmagupta, mathematician par excellence, Resonance, March 2012, 247 - 252. 
[13] SaKHYa, Ganitasārakaumudī; the Moonlight of the Essence of Mathematics, by Thakkura Pheriü; edited with Introduction, Translation, and Mathematical Commentary, Manohar Publishers, New Delhi 2009.

[14] T.A. Saraswati Amma, Geometry in Ancient and Medieval India, Motilal Banarasidas Publishers, 1999.

[15] S.N. Sen and A.K. Bag, The Śulvasūtras, Indian National Science Academy, New Delhi, 1983.

[16] Kripa Shankar Shukla (Ed. and Tr.), The Pātīgaitta of Śrīdharacārya with an anciet Sanskrit commentary, Hindu Astronomical and Mathematical Texts Series No. 2, Department of Mathematics and Astronomy, Lucknow University, Lucknow, 1959.

[17] John Taylor, Lilawati, or a Treatise on Arithmetic and Geometry by Bhascara Acharya, The Courier Press, Bombay, 1816.

S.G. Dani

Department of Mathematics

Indian Institute of Technology Bombay

Powai, Mumbai 400005

India

E-mail: sdani@math.iitb.ac.in 